\title{
Prospective analysis of antiribonucleoprotein antibodies in systemic lupus erythematosus
}

\author{
B. BRESNIHAN, R. GRIGOR, AND G. R. V. HUGHES \\ From the Rheumatology Unit, Department of Medicine, Royal Postgraduate Medical School, Hammersmith \\ Hospital, London W12
}

SUMMARY A prospective analysis of 50 successive patients with systemic lupus erythematosus, seen over a 4-year period, has been completed. 336 sera were examined for the presence of antibody to ribonucleoprotein using a counterimmunoelectrophoresis assay. Antibody was present in the sera of $16 \%$ of patients and was detectable in about the same titre throughout the course of the disease. The presence of the antibody did not appear to identify a subgroup of lupus patients with individual clinical characteristics.

Antibody to ribonucleoprotein (RNP) is present in high titre in patients with mixed connective tissue disease (MCTD) (Sharp et al., 1972). Anti-RNP antibody has also been shown in low titre in the serum of some patients with systemic lupus erythematosus (SLE), and it has been suggested that its presence is associated with a low prevalence of nephritis (Reichlin and Mattioli, 1972) and a favourable response to immunosuppressive therapy (Sharp et al., 1971). Others, however, have observed renal disease as a prominent feature in lupus patients with anti-RNP antibody, but suggested that those clinical features frequently present in MCTD, such as Raynaud's phenomenon and myositis, occurred more often (Dorsch et al., 1977). This study is part of a prospective analysis of 50 successive patients with SLE. We have attempted to clarify some of the observations which may remain inconclusive as a result of retrospective investigations.

\section{Patients and methods}

Fifty patients comprising a group of successive lupus patients seen at Hammersmith Hospital between 1973 and 1976 were studied. All were admitted to hospital on at least one occasion regardless of disease activity. Diagnosis of SLE was based on clinical criteria (Cohen et al., 1971) and the presence of antibodies to DNA. Analysis of each patient was based on a comprehensive protocol completed during the period of each hospital admission.
Included in the clinical evaluation were special investigations of pulmonary, cardiac, neurological, and renal function. The clinical features considered to reflect a disorder of neurological function were behavioural patterns inappropriate to the known personality of the patient, organic confusional or depressive states, grand mal convulsions, or definite focal abnormalities. Renal disease was shown by the presence of an abnormal biopsy, proteinuria of at least $1 \mathrm{~g} /$ day on at least two occasions, or an abnormal urinary sediment. The detailed clinical features have been described elsewhere (Grigor et al., 1977). Most of the 50 patients were subsequently followed as outpatients and seen at varying intervals depending on their clinical status. Sera were obtained at almost all clinic attendances and stored in aliquots at $-20^{\circ} \mathrm{C}$ until the time of testing.

\section{IMMUNOLOGICAL METHODS}

Anti-extractable nuclear antigen (ENA) antibodies were detected by a counterimmunoelectrophoresis assay (Bresnihan et al., 1977). A lyophilized preparation of a saline-soluble acetone extract of rabbit thymus (Pel-Freeze Biologicals Inc., Rogers, Arkansas) was used as a source of RNP and Sm antigens. Sera showing a positive precipitin line were again tested with RNase-treated antigen to establish whether the reaction was against the RNasesensitive RNP or the RNase-resistant Sm antigen. Anti-DNA antibodies were measured using the Farr ammonium sulphate precipitation technique (Wold et al., 1968). ${ }^{14} \mathrm{C}-\mathrm{DNA}$ was obtained from the Radiochemical Centre, Amersham. Results were 
expressed as percentage ${ }^{14} \mathrm{C}-\mathrm{DNA}$ bound by the serum. Serum C3 values were estimated by radial immunodiffusion and the results expressed as percentage $\mathrm{C} 3$ value of pooled normal sera.

\section{Results}

INCIDENCE OF ANTI-ENA ANTIBODIES AND RESPONSE TO TREATMENT

A total of 336 sera from the 50 patients was available for analysis. Anti-RNP antibody was present in the sera of $16 \%$ of the patients studied (Table 1 ). Anti-RNP was present alone in $10 \%$ while anti-Sm was present alone in only $4 \%$. The titre of anti-RNP and anti-Sm antibodies ranged between $1: 4$ and $1: 32$, but in individual patients neither titre changed by more than a single dilution irrespective of the disease activity or the response to corticosteroids.

\section{CLINICAL FEATURES ASSOCIATED WITH}

\section{ANTI-ENA ANTIBODIES (TABLE 2)}

The major clinical features of patients with anti-RNP antibody are compared with those in patients lacking anti-RNP antibody. Neurological abnormalities occurred in $50 \%$ of the anti-RNP positive group and biopsy-proven nephritis also occurred in $50 \%$. Of the 4 patients having anti-RNP antibody and nephritis, 2 had a proliferative glomerulonephritis requiring cytotoxic drugs in addition to corticosteroids. Significant proteinuria occurred in all 4 , while a reduced creatinine clearance was seen repeatedly in 3 . Thus, severe renal disease was associated with anti-RNP antibodies in some patients, though none of this group has died. The incidence of renal disease

Table 1 Anti-RNP and Anti-Sm antibodies in SLE

\begin{tabular}{llr}
\hline & No. & $\%$ \\
\hline Anti-RNP ( \pm anti-Sm) & 8 & 16 \\
Anti-Sm ( \pm anti-RNP) & 5 & 10 \\
Anti-RNP alone & 5 & 10 \\
Anti-Sm alone & 2 & 4 \\
\hline
\end{tabular}

Table 2 Major clinical features of patients with and without anti-RNP antibodies

\begin{tabular}{lll}
\hline & $\begin{array}{l}\text { Anti-RNP } \\
\text { positive } \\
(n=8)\end{array}$ & $\begin{array}{l}\text { Anti-RNP } \\
\text { negative } \\
(n=42)\end{array}$ \\
\hline Renal disease & 4 & 16 \\
CNS disease & 4 & 21 \\
Arthritis/arthralgia & 8 & 41 \\
Raynaud's phenomenon & 2 & 14 \\
Cutaneous vasculits & 6 & 29 \\
Myositis/myalgia & 1 & 15 \\
Pleurisy/pericarditis & 4 & 24 \\
Lymphadenopathy & 4 & 11 \\
Hypergammaglobulinaemia & 8 & 24 \\
Lymphopenia & 4 & 37 \\
\hline
\end{tabular}

was not increased in those patients with anti-S antibody. Of the anti-RNP negative group only one patient died of renal disease. Only lymphadenopath and hypergammaglobulinaemia, of the clinical features commonly associated with MCTD, we seen more frequently in that group with anti-RN antibody, but the differences were not statisticalf significant.

ANTI-DNA ANTIBODY AND SERUM COMPLEMENC LEVELS IN PATIENTS WITH ANTI-ENA

\section{ANTIBODIES}

Anti-DNA antibodies were detected in the serum of all patients at some stage during the course of the disease. Table 3 shows that the mean percentas DNA binding by sera from anti-RNP positipe patients was similar to that of anti-RNP negativg patients. A surprising observation was that $50 \%$ of the sera from the anti-RNP positive patients hat lowered C3 values compared with $22 \%$ of sera from the anti-RNP negative patients (Table 4). The mean C3 levels of the anti-RNP positive sera was signifio antly lower than the level in anti-RNP negative se $(P<0.001)$.

\section{Discussion}

The $16 \%$ incidence of anti-RNP antibodies repote in this study was similar to the $19 \%$ incidenee reported previously in a study which included patients with SLE (Bresnihan, et al., 1977). Thege figures are lower than those reported by others (Sharp et al., 1971; Kurata and Tan, 1976; Dorse et al., 1977). That this variation is unlikely to be due to a lack of sensitivity of the counterimmung electrophoresis assay was suggested by the data of Kurata and Tan (1976), who found anti-RN

Table 3 Anti-DNA antibody levels in patients with anti-RNP antibodies

\begin{tabular}{|c|c|c|c|}
\hline & \multicolumn{2}{|c|}{ No. of sera } & $\begin{array}{l}\text { DNA binding } 0 \\
(m e a n \pm S E M\end{array}$ \\
\hline $\begin{array}{l}\text { Anti-RNP positive } \\
\text { Anti-RNP negative }\end{array}$ & \multicolumn{2}{|l|}{$\begin{array}{l}72 \\
243\end{array}$} & $\begin{array}{l}62 \cdot 9 \pm 3 \cdot 4 \\
60 \cdot 4 \pm 1 \cdot 9\end{array}$ \\
\hline \multicolumn{4}{|c|}{ *Normal DNA binding $<30 \%$. } \\
\hline \multicolumn{4}{|c|}{$\begin{array}{l}\text { Table } 4 \text { Serum } C 3 \text { values in patients with anti-RNPW } \\
\text { antibodies }\end{array}$} \\
\hline & No. of sera & No. low C3 & $\begin{array}{l}\text { Serum } C 3^{*} \text { 它 } \\
(m e a n \pm S E M)\end{array}$ \\
\hline $\begin{array}{l}\text { Anti-RNP positive } \\
\text { Anti-RNP negative }\end{array}$ & $\begin{array}{r}52 \\
167\end{array}$ & $\begin{array}{l}26(50 \%) \\
36(22 \%)\end{array}$ & $\begin{array}{l}59 \cdot 6 \pm 4 \cdot 2 \\
78 \cdot 3 \pm 2 \cdot 0 \\
P<0 \cdot 001\end{array}$ \\
\hline
\end{tabular}


antibody in $46 \%$ of SLE patients using an identical source of antigen and assay system. It is possible that the lower incidence we found was the result of variations in the patient population available for study in England and the US, or to differences in patient selection. It is important to emphasize that there was no apparent selection bias of the patients included in this study as the group included successive patients referred to several different specialities, including rheumatology, nephrology, and haematology.

All patients with anti-RNP antibody continued to have detectable levels of the same antibody throughout the course of their disease. Furthermore, there was at no time a substantial change in the titre of antibody regardless of disease activity or clinical response to therapy.

Renal disease was found with equal frequency in the anti-RNP positive and negative patients. Sharp et al. (1971) have suggested that the presence of antiRNP antibody in patients with renal disease identified those patients likely to have a better response to immunosuppressive therapy. This has been supported by others, who observed a tendency towards a lower prevalence of nephritis in patients with antibody to RNP (Reichlin and Mattioli, 1972; Liebfarth and Persellin, 1976). While the group of patients with renal disease having anti-RNP antibody in this study was too small to allow statistical evaluation, the course of the renal disease did not suggest that the response to therapy was related to the presence of anti-RNP antibody. That severe renal disease may be present in the anti-RNP positive patients is in agreement with the data of Dorsch et al. (1977).

It has been suggested that lupus patients with antiRNP antibody have a greater incidence of those clinical features, such as Raynaud's phenomenon and myositis, frequently seen in patients with MCTD (Dorsch et al., 1977; Liebfarth and Persellin, 1976). However, this is not supported by our data. The incidence of those disease manifestations commonly seen in MCTD was not greater in the antiRNP positive group of patients. In particular, Raynaud's phenomenon was seen in only $25 \%$ of the anti-RNP positive patients.

The observation that the anti-RNP positive group had a statistically greater incidence of hypocomplementaemia than the anti-RNP negative group was surprising, and suggests that this antibody may be involved in immune complex formation. Winfield $e t$ al. (1975) have observed anti-RNP antibody in the cryoprecipitates of some patients with SLE. Furthermore, Parker and Marion (1977) have demonstrated complement-fixing immune complexes in $100 \%$ of sera from patients with MCTD and suggested that anti-RNP containing complexes may contribute to tissue injury. It is hoped that current studies will clarify the possible role of anti-RNP containing complexes.

In conclusion, the data reported in this prospective study indicate that anti-RNP antibody is present in a minority of SLE patients. It does not appear to identify a subpopulation with individual clinical characteristics.

We are grateful for the technical assistance of Christopher Bunn and for the secretarial assistance of Elizabeth Turner.

\section{References}

Bresnihan, B., Bunn, C., Snaith, M. J., and Hughes, G. R. V. (1977). Antiribonucleoprotein antibodies in the connective tissue diseases. British Medical Journal, 1, 610-612.

Cohen, A. S., Reynolds, W. E., Franklin, E. C., Kulka, J. P., Ropes, M. W., Shulman, L. E., and Wallace, S. L. (1971). Preliminary criteria for the classification of systemic lupus erythematosus. Bulletin on Rheumatic Diseases, 21, 643-648.

Dorsch, C. A., Feinglass, E. J., and Stevens, M. B. (1977). Clinical significance of antibodies to extractable nuclear antigen (ENA) in systemic lupus erythematosus (SLE). Arthritis and Rheumatism, 20, 114.

Grigor, R. R., Edmonds, J. P., Lewkonia, R. M., Bresnihan, B., and Hughes, G. R. V. (1977). Systemic lupus erythematosus. A prospective analysis. Annals of the Rheumatic Diseases (in press).

Kurata, N., and Tan, E. M. (1976). Identification of antibodies to nuclear acidic antigens by counter-immunoelectrophoresis. Arthritis and Rheumatism, 19, 574-580.

Liebfarth, J. H., and Persellin, R. H. (1976). Characteristics of patients with serum antibodies to extractable nuclear antigens. Arthritis and Rheumatism, 19, 851-856.

Parker, M. D., and Marion, T. (1977). Circulating complement-fixing immune complexes in mixed connective tissue disease. Arthritis and Rheumatism, 20, 120.

Reichlin, M., and Mattioli, M. (1972). Correlation of a precipitin reaction to an RNA protein antigen and a low prevalence of nephritis in patients with systemic lupus erythematosus. New England Journal of Medicine, 286, 908-911.

Sharp, G. C., Irvin, W. S., La Rogue, R. L. Velez, C., Daly, V., Kaiser, A. D., and Holman, H. R. (1971). Association of autoantibodies to different nuclear antigens with clinical patterns of rheumatic disease and responsiveness to therapy. Journal of Clinical Investigation, 50, 350-359.

Sharp, G. C., Irvin, W. S., Tan, E. M., Gould, R. G., and Holman, H. R. (1972). Mixed connective tissue diseasean apparently distinct rheumatic disease syndrome associated with a specific antibody to an extractable nuclear antigen (ENA). American Journal of Medicine, 52, 148-159.

Winfield, J. B., Koffler, D., and Kunkel, H. G. (1975). Specific concentration of polynucleotide immune complexes in the cryoprecipitates of patients with systemic lupus erythematosus. Journal of Clinical Investigation, 56, 563-570.

Wold, R. T., Young, F. E., Tan, E. M., and Farr, R. S. (1968). Deoxyribonucleic acid antibody; method to detect its primary interaction with deoxyribonucleic acid. Science, 161, 806-807. 